\title{
Making Sense of Congressional Intent: Statutory Interpretation and Welfare Policy
}

\author{
Between the Lines: Interpreting Welfare Rights. By R. Shep Melnick. \\ Washington, D.C.: Brookings Institution, 1994. Pp. viii, 344. \$36.95 \\ (hardcover) $\$ 16.95$ (paper).
}

\section{Robert A. Katzmann ${ }^{\dagger}$}

In the last decade, the study of statutory interpretation has taken on new life. In part, the statutory work of the Supreme Court has assumed growing importance because the legislation under review touches vital issues affecting the nation. A court that pronounces what Congress meant in such areas as civil rights, ${ }^{1}$ voting rights, ${ }^{2}$ and gender discrimination ${ }^{3}$ will almost certainly be the object of heightened attention. Justice Antonin Scalia has fueled discussion about statutory interpretation with his persistent criticism of the way courts use legislative history, materials beyond the words of statutes. He has since been joined by other Justices with interests in courts and legislation, including David Souter, Ruth Bader Ginsburg, and Stephen Breyer.' Concern with how the judiciary makes sense of legislation has reached Congress itself. Both the

\footnotetext{
* Professor of Politics, Brandeis University.

$\dagger$ Walsh Professor of American Government and Professor of Law, Georgetown University: President. Governance Institute; and Visiting Fellow, Brookings Institution.

1. See, e.g., Metro Broadcasting, Inc. v. FCC. 497 U.S. 547 (1990); Lorance v. AT\&T Technologies, Inc., 490 U.S. 900 (1989); Martin v. Wilks, 490 U.S. 755 (1989); Wards Cove Packing Co. v. Atonio. 490 U.S. 642 (1989); Patterson v. McLean Credit Union, 485 U.S. 617 (1988).

2. See, e.g., Johnson v. De Grandy, 114 S. CL. 2647 (1994); Holder v. Hall. 114 S. Cl. 2581 (1994): Shaw v. Reno, 113 S. CL. 2816 (1993).

3. See, e.g., Franklin v. Gwinett County Pub. Sch., II2 S. CL 1028 (1992); UAW v. Johnson Controls, Inc., 499 U.S. 187 (1991).

4. See, e.g., Chisom v. Roemer, 501 U.S. 380, 404 (1991) (Scalia, J., dissenting); Jett v. Dallas Indep. Sch. Dist., 491 U.S. 701, 738-39 (1989) (Scalia, J., concurring in part and concurring in the judgment): Green v. Bock Laundry Mach. Co., 490 U.S. 504, 527 (1989) (Scalia. J., concurring in the judgment); Hirschey v. FERC, 777 F.2d 1, 7-8 (D.C. Cir. 1985) (Scalia, J., concurring in the judgment); Rober A. Katzmann, Summary of Proceedings, in JUDGES AND LEGISLATORS: TOWARD INSTITUTIONAL COMITY 162. 171-75 (Robert A. Katzmann ed., 1988) [hereinafier JUDGES AND LEGISLATORS] (quoting Justice Scalia).

5. See, e.g., United States v. Thompson/Ctr. Arms Co., 112 S. Ct. 2102, 2109 n.8 (1992) (Souter, J.) ("Justice Scalia upbraids us for reliance on legislative history, his St. Jude of the hagiology of statutory construction... . The shrine, however, is well peopled (though it has room for one more) and its congregation has included such noted elders as Mr. Justice Frankfurter ... . "); Ruth Bader Ginsburg \& Peter Huber, The Intercircuit Committee, 100 HARV. L. REV. 1417 (1987); Stephen Breyer. On the Uses of Legislative History in Interpreting Starutes, 65 S. CAL L. REV. 845 (1992).
} 
House Judiciary Committee's Subcommittee on Courts, Intellectual Property, and the Administration of Justice ${ }^{6}$ and the Joint Committee on the Organization of Congress ${ }^{7}$ have conducted hearings on legislative-judicial relations. Statutory interpretation has sparked attention not only in scholarly books ${ }^{8}$ and journals, ${ }^{9}$ but even in the popular media. ${ }^{10}$

At issue is the integrity of the legislative and judicial processes. When courts interpret legislation, as former Judge Abner Mikva has observed, they become an integral component of the legislative process. ${ }^{11}$ If courts have difficulty understanding the legislative process that they interpret or Congress does not provide the courts with direction as to its meaning, then both branches have a problem deserving consideration. Beyond that, how the First and Third branches interact has implications beyond those branches; the nature of that relationship affects the shape and development of policy. In that sense, the concern is with how the judiciary and the legislature work, either independently, together, or at cross-purposes, as they influence policymaking.

The interplay of Congress and the courts has vital ramifications for the administrative state itself. ${ }^{12}$ When the judiciary interprets a statute or

6. See Statutory Interpretation and the Uses of Legislative History: Hearing Before the Subcomm. on Courts, Intellectual Property, and the Administration of Justice of the House Comm. on the Judiciary, 10Ist Cong., 2d Sess. (1990) [hereinafter Hearings on Statutory Interpretation]. As Subcommittee Chairman Robert Kastenmeier put it: "This is more than just an academic debate." Id. at 2. Judicial doctrines of statutory interpretation "may have a profound effect on the way Congress should be drafting legislation." Id.

7. See Interbranch Relations: Hearings Before the Joint Comm. on the Organization of Congress, 103d Cong., lst Sess. 76, 298 (1993) [hereinafter Hearings on Interbranch Relations].

8. See, e.g., WILLIAM N. ESKRIDGE, JR., DYNAMIC STATUTORY INTERPRETATION (1994) [hereinafter DYNAMIC STATUTORY INTERPRETATION]; WILLIAM N. ESKRIDGE, JR. \& PHLIP P. FRICKEY, LEGISLATION:

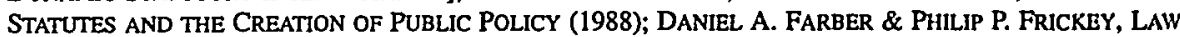

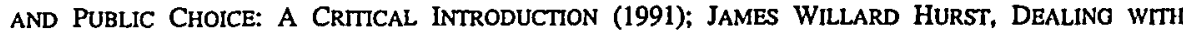
STATUTES (1982).

9. This rich literature is difficult to summarize succinctly. Important recent work includes Daniel A. Farber, Statutory Interpretation and Legislative Supremacy, 78 GEO. L.J. 281 (1989); Charles O. Jones, A Way of Life and Law: Presidential Address, American Political Science Association, 1994, 89 AM. POL. SCI. REV. 1 (1995); Jerry L. Mashaw, Textualism, Constitutionalism, and the Interpretation of Federal Statutes, 32 WM. \& MARY L. REV. 827 (1991); Daniel B. Rodriguez, Statutory Interpretation and Political Advantages, 12 INT'L REV. L. \& ECON. 217 (1992); Edward L. Rubin, Law and Legislation in the Administrative State, 89 CoLUM. L. REV. 369 (1989); Frederick Schauer, Statutory Construction and the Coordinating Function of Plain Meaning, 1990 SUP. CT. REv. 231; Peter L. Strauss, When the Judge Is Not the Primary Official with Responsibility To Read: Agency Interpretation and the Problem of Legislative History, 66 CHI.-KENT L. REv. 321 (1990); Cass R. Sunstein, Interpreting Statutes in the Regulatory State, 103 HARV. L. REV. 405 (1989); Symposium, A Reevaluation of the Canons of Statutory Interpretation, 45 VAND. L. REV. 529 (1992); Symposium, The Case of the Speluncean Explorers: Contemporary Proceedings, 61 GEO. WASH. L. REV. 1754 (1993).

10. James H. Andrews, Breyer Would Join Court's Swing Center, Christian SCI. MonIToR, July 18, 1994, at 6; Linda Greenhouse, Portrait of a Pragmatist: Confirmation Hearing for Breyer Elicits His Emphasis on Rulings' Lasting Effects, N.Y. TIMEs, July 14, 1994, at A1, D22; Robert A. Katzmann, Justice Breyer: A Rival for Scalia on the Hill's Intent, Roll CALL, May 31, 1994, at 5.

11. Abner J. Mikva, Getting the Law To Be Less Common, 50 OHo ST. L.J. 979, 982 (1989); Abner J. Mikva, Reading and Writing Statutes, 48 U. PITT. L. REV. 627, 627-28 (1987).

12. See, e.g, Martin ShapiRo, Who Guards the Guardians? Judicial Control of ADMINISTRATION (1988); Colin S. Diver, Statutory Interpretation in the Administrative State, 133 U. PA. L. REV. 549 (1985); Cynthia R. Farina, Statutory Interpretation and the Balance of Power in the 
mandates or restrains executive action, it perforce affects the administrative process. A court's decisions can influence not only the balance of forces within Congress, but also the relationships among agencies or competing factions within the bureaucracy, and the capacity of the President to control the executive branch. "Policymaking is dynamic and complex; it can be conceived as a continuum of institutional processes [judicial, legislative, and administrative], sometimes acting independently, but often interacting in subtle and perhaps not always conscious ways to influence the behavior of other processes."13

In his major book, Between the Lines: Interpreting Welfare Rights, ${ }^{14} \mathrm{R}$. Shep Melnick deepens our understanding of the intricate relationship between the judiciary and the Congress in policymaking. Through three rich case studies-Aid to Families with Dependent Children (AFDC), food stamps, and education for the handicapped-he examines how the federal judiciary, by interpreting statutes, has expanded eligibility, enlarged benefits, and moved control from the states to the federal government. If much of the previous literature on statutory interpretation has focused on how judges might better interpret statutes, Melnick approaches the matter from the perspective of policy outcomes-asking "[w]hat difference did it make that the courts adopted this interpretation rather than competing ones?"1s His intention is to study both issues of process and of policy. With regard to the former, his objective is to examine how the courts affected the balance of power between the states and the federal government, between the Congress and the President, and between Congress as a whole and its committees; to explain why different institutional patterns occur in different policy areas; and to assess Justice Scalia's claim that heavy reliance on legislative history threatens to "convert[] a system of judicial construction into a system of committee-staff prescription." 16

With respect to matters of policy, Melnick explores basic beliefs about the welfare state, the responsibilities of the government to its poor, and the obligations of citizens to provide for themselves as these beliefs are reflected in court decisions interpreting the AFDC title of the Social Security Act, the Food Stamp Act, and the Education for All Handicapped Children Act (EAHCA). He endeavors to determine the extent to which members of Congress shared these views, and the degree to which the assumptions of members of Congress and the judiciary changed over time.

\footnotetext{
Administrative State, 89 COLUM. L. REv. 452 (1989): Peter H. Schuck \& E. Donald Elliot, To the Chevron Station: An Empirical Study of Federal Administrative Law, 1990 DUkE LJ. 984.

13. ROBERT A. KATZMANN, INSTTUTIONAL DISABILTTY: THE SAGA OF TRANSPORTATION POLICY For THE DISABLED 9 (1986).

14. R. SHEP MELNICK, BETWEen tHE LINES: INTERPRETING WelfARE RIGits (1994).

15. Id. at 20 .

16. Hirschey v. FERC, 777 F.2d 1. 8 (D.C. Cir. 1985).
} 
Part I of this Review describes the political, institutional, and legal contexts that shape Melnick's analysis and summarizes his conclusions with regard to the effect of the courts in shaping policy within the three areas he examines. In Part II, I discuss the impact of Melnick's findings on two current academic debates, the first over whether courts are capable of effecting social change, and the second on the viability of competing theories of statutory interpretation. If Between the Lines effectively illustrates that legislative history and, all too frequently, statutory language provide little guidance to courts trying to discern legislative meaning, Part III argues that this state of affairs can be ameliorated. I describe a series of ongoing projects designed to overcome some of the problems that Melnick identifies.

\section{CONTEXT}

\section{A. Politics, Institutional Process, and Law}

One of the many strengths of this book is that it grounds specific case studies of statutory interpretation in the larger context of the political arena in which legislation is conceived. Melnick rightly describes two important developments that affected the judicial interpretation of statutes in his case studies: the ever-expanding responsibilities of the federal government and the fragmentation of power at the national level-between Congress and the executive, and within the legislature itself as congressional authority became increasingly decentralized and the integrative power of political parties diminished. ${ }^{17}$

These changes have affected the design of statutes in a variety of ways. Legislation in recent decades has tended to combine both specificity and ambiguity. Some statutes leave key terms undefined and in effect give to others-federal, state, and local officials as well as judges-the responsibility of adding flesh to the statutory skeleton. The EAHCA, for instance, mandates that states provide every handicapped child with a "free appropriate public education,"18 but does not spell out what that means. Section 504 of the Rehabilitation Act of 1973 declares that "no otherwise qualified handicapped individual ... shall, solely by reason of his handicap, ... be subjected to discrimination under any program or activity receiving Federal financial assistance." 19 In the absence of clear definition as to the meaning of "otherwise qualified handicapped individual," judges and officials charged with

17. MELNICK, supra note 14 , at $28-31$.

18. 20 U.S.C. $\$ 1401$ (1988).

19. 29 U.S.C. \& 794 (1988). 
implementing the law have for two decades borne most of the responsibility for fashioning its scope. ${ }^{20}$

At the same time, legislation and accompanying committee reports have often become more detailed; with each reauthorization, the entitlement laws, which are the subject of Melnick's book, have become more specific. The House report on the 1977 amendments to the Food Stamp Act occupied 869 pages and "contained advice on such matters as how late intake offices should be open and which court decisions had identified the proper method for counting the income of migrant workers." ${ }^{21}$ Congressional "micromanagement" reflected legislative distrust of the executive branch, extending to deadlines, procedures, and performance standards. ${ }^{2}$ In addition, demands placed on states increased, with a variety of regulatory controls-direct orders, crosscutting requirements, crossover sanctions, and funding cutoffs. ${ }^{23}$ Still another feature of the political context was congressional facilitation of litigation. Many acts directly authorized suits by private parties to enforce regulatory requirements. Still others contained liberal standing requirements for those contesting agency rules. ${ }^{24}$

Melnick also writes that federal courts developed devices that enlarged their role in interpreting the law of entitlement. One such method was the decline of judicial deference to administrators' interpretation of statutes, an approach that had special force until the Court's enunciation of the Chevron ${ }^{25}$ doctrine in 1984. Federal courts in the 1960's and 1970's, as Richard Stewart has written, focused on fidelity to procedures to assure fair representation for all affected parties, and then made use of the "hard look" doctrine to delve into agencies' substantive determinations. ${ }^{26}$ Second, courts augmented their powers by interpreting statutes in ways that allowed them to curb the discretion of state officials. Federal judges, Melnick claims, helped alter federal-state relations by, in effect, turning "conditions attached to federal grants-previously enforced only through the termination of federal aid-into individual rights enforceable through court injunctions." ${ }^{.27}$ A third mechanism involved an increased reliance on legislative history and broad statements of statutory purpose to expand benefits and ease eligibility restrictions. Judges, according to Melnick, combed the legislative history to find support for their

20. See, e.g., Southeastem Community College v. Davis, 442 U.S. 397 (1979); Doc v. New York Univ., 666 F.2d 761 (2d Cir. 1981).

21. MELNICK, supra note 14 , at 34 .

22. Id. at 32 .

23. Id. at 33 .

24. Id. at 34 .

25. Chevron v. Natural Resources Defense Council, 467 U.S. 837 (1984).

26. Richard B. Stewart, The Reformation of American Administrative Law, 88 HARV. L. REV. 1669. $1670-71,1679-80$ (1975).

27. MELNICK, supra note 14 , at 45 . 
interpretations so that their decisions were perceived to reflect congressional purposes. ${ }^{28}$

Melnick argues that reliance on broad statements of statutory purpose subtly shifts the burden of proof in favor of those who seek to expand federal programs because such statements generally are grandiloquently worded, emphasizing goals rather than costs. ${ }^{29} \mathrm{~A}$ most significant development with regard to entitlement statutes, the author believes, was the shift from a judicial presumption of administrative regularity to one that administrators must justify deviations from the principle of "actual need." 30 The claim is that federal judges would invalidate state rules and federal regulations, "not because they transgressed clear statutory language, but because they failed to take into account the actual need of potential beneficiaries." 31

These judicial doctrines had a temporal quality. By the late 1980's, each device seemed to be losing force. With the Chevron decision in 1984, the Supreme Court ruled that a reviewing tribunal "may not substitute its own construction of a statutory provision for a reasonable interpretation made by the administrator of an agency." 32 When a statute is silent or ambiguous with respect to a specific issue, the only question before the court is whether the agency adopted a "permissible construction of the statute." ${ }^{33}$ In other words, the Supreme Court made it easier for an administrator's interpretation to prevail. Moreover, as a consequence of a variety of Supreme Court opinions, judicial control over state regulations loosened. Fewer implied rights of action were recognized. ${ }^{34}$ In addition, Justice Scalia's critique of legislative history appears to have had some effect, with the Court resorting less to such materials when reliance on the words of a statute seems to be dispositive. ${ }^{35}$

\section{B. The Impact of Statutory Interpretation on Public Policy: Interpreting Welfare Rights}

The impact of the federal courts was most striking with regard to the AFDC program. For more than thirty years-from the legislation's passage in 1935 until 1968-state governments had much discretion in their welfare programs, constrained only by a relatively few rules contained in Title IV of the Social Security Act. $^{36}$ Congress repeatedly failed during this period to

\footnotetext{
28. Id. at 251 .

29. Id. at 54 .

30. Id. at 54-59.

31. Id. at 45 .

32. Chevron v. Natural Resources Defense Council, 467 U.S. 837, 844 (1984) (footnote omitted).

33. Id. at 843 (footnote omitted).

34. See, e.g., Atascadero State Hosp. v. Scanlon, 473 U.S. 234 (1985); Pennhurst State Sch. \& Hosp. v. Halderman, 451 U.S. 1 (1981).

35. See Hearings on Interbranch Relations, supra note 7, at 79-80 (statement of Judge Patricia M.

36. See MELNICK, supra note 14 , at $68-72$.
} Wald). 
enact nationally uniform eligibility requirements and benefit levels. The Supreme Court's influence was perhaps most dramatic between 1968 and 1972. When interpreting Title IV of the Social Security Act, the high tribunal expressly disapproved of a Department of Health, Education, and Welfare policy that allowed states to "vary eligibility requirements from the federal standards without express or clearly implied congressional authorization." 37 Because the federal statute hardly addressed the eligibility standard, the Court's interpretation raised questions about almost all of the AFDC rules in every state. ${ }^{38}$ The federal courts, a Senate Finance Committee report stated,

used the very broadness of the Federal statute (intended to allow States more latitude) against the States by saying sometimes that anything the Congress did not expressly prohibit it must have intended to require-and sometimes that what the Congress did not expressly permit it must have intended not to permit. ${ }^{39}$

The lower courts expanded the Supreme Court's reading of Title IV, invalidating state rules in such matters as verification procedures, methods for determining income, and penalties for failure to register for work programs or to identify the fathers of children receiving benefits. ${ }^{40}$ In time, the Supreme Court criticized the circuit courts for their alleged "departure from ordinary principles of statutory interpretation." ${ }^{* 1}$ As Melnick explains, by the mid1980 's the Court routinely ordered the circuit courts to defer to state and federal administrators. ${ }^{42}$

In interpreting the Food Stamp Act during the 1970's, the other federal courts were much influenced by the U.S. Court of Appeals for the D.C. Circuit, which viewed the legislation as "a shift from supplementing the diets of low-income households to guaranteeing those households the opportunity for an adequate diet." 43 Courts ruled that Congress meant to "assure that no eligible family need go malnourished." As a means of securing this statutory right to a "nutritionally adequate diet," the courts required the Department of Agriculture to offer benefits to more households, expand outreach efforts to poor families, and make certification procedures less

37. Carleson v. Remillard, 406 U.S. 598, 601 (1972).

38. MELNICK, supra note 14, at 91-92.

39. S. REP. No. 1230, 92 d Cong., 2d Sess. 16 (1972).

40. See MELNICK, supra note 14 , at 104-08.

41. Burns v. Alcala, 420 U.S. 575, 580 (1975).

42. See, e.g., MELNICK, supra note 14, at 104-06.

43. Rodway v. United States Dep't of Agric., 514 F.2d 809, 820 (D.C. Cir. 1975).

44. Id.

45. Id. 
unwieldy and intrusive. ${ }^{46}$ Court rulings effectively prevented the Ford Administration from unilaterally shrinking the food stamp program. ${ }^{47}$

Moreover, court decisions crucially influenced the lengthy congressional negotiations resulting in the enactment of the food stamp amendments of 1977. Food stamp advocates, who were leaning towards reaching a compromise with the Ford Administration, decided after the court decision enjoining the Ford Administration's rules that they could risk waiting for a new Congress and perhaps a new Democratic President. Their gamble was worth taking. ${ }^{48}$ President Jimmy Carter signed new legislation in $1977^{49}$ that was far more expansive than the bill Congress almost sent to Gerald Ford a year before.

With respect to the EAHCA, two federal court decisions in the early 1970's, $P A R C^{50}$ and Mills, ${ }^{51}$ writes Melnick, provided the political catalyst and the model for federal legislation. Those opinions required state and local systems to provide a "free appropriate public education" to all disabled children, and also created procedural safeguards to ensure these substantive rights. These decisions raised costs substantially for some states, and as a consequence school officials sought more federal financial assistance. ${ }^{52}$ For their part, congressional supporters of those with disabilities believed that states should have to show that they protected the substantive and procedural rights of the disabled as a condition for securing federal funds. ${ }^{53}$ In the aftermath of the passage of the EAHCA, litigation increased-although sponsors had argued lawsuits would be reduced as a consequence of the bill's passage. ${ }^{54}$ School systems were sued for failure to provide students with an "appropriate education" or "related services." The Supreme Court, in its only ruling on the "appropriate education" standard, endorsed a deferential approach towards review. ${ }^{55}$ Then Justice Rehnquist wrote that the act is "by no means an invitation to the courts to substitute their own notions of sound educational policy for those of the school authorities which they review." 56 Nevertheless, Melnick shows that many district and circuit court judges have interpreted the statute to strike down the "individualized education programs" submitted by school officials in favor of more costly plans that promise to provide increased benefits to children with disabilities. ${ }^{57}$

46. See MELNICK, supra note 14, at 208-13.

47. Id. at $217-21$.

48. Id. at 221 .

49. Food Stamp Act of 1977, Pub. L. No. 95-113, 91 Stat. 913, 958 (codified as amended at 7 U.S.C. $\S \S 2011-2030$ (1988)).

50. Pennsylvania Ass'n for Retarded Children v. Pennsylvania, 343 F. Supp. 279 (E.D. Pa. 1972).

51. Mills v. Board of Educ., 348 F. Supp. 866 (D.D.C. 1972).

52. MELNICK, supra note 14 , at $235-36$.

53. Id. at 236.

54. Id. at 140 .

55. Board of Educ. v. Rowley, 458 U.S. 176 (1982).

56. Id. at 206.

57. See MELNICK, supra note 14 , at 172-75. 


\section{IMPLICATIONS}

Melnick's rich case studies have important implications for scholars interested in the role of courts in the policy process, and for those attempting to set forth broad theories of statutory interpretation. The careful empirical studies in Between the Lines provide support for some of the conclusions drawn by scholars functioning at a greater level of abstraction, but also cast doubt upon others.

\section{A. The Courts, Statutory Interpretation, and Social Change}

Between the Lines should be read as part of the ongoing debate, spurred by Gerald N. Rosenberg's influential The Hollow Hope, ${ }^{\text {sg }}$ about the role of the judiciary in effecting social change. Rosenberg argues that courts are "virtually powerless to produce change" are part of the judicial system. Even more strongly, he writes that "U.S. courts can almost never be effective producers of significant social change." Indeed, the "lure of litigation," he claims, "siphons off crucial resources and talent, and runs the risk of weakening political efforts."62 By turning to an "institution [the judiciary] that is constrained from helping them," institutional reform litigation may hamper advances by "providing only an illusion of change.".63

Melnick's work provides evidence for Peter Schuck's criticism that The Hollow Hope "neglects the repetitive, dialogic nature of the interactions between courts, legislatures, agencies, and other social processes, as well as the political synergy that some litigation engenders. "64 Indeed, each of Melnick's case studies undermines the limited view of judicial impact. Interest groups initiating litigation did not rely exclusively on lawsuits, but used courts as one element of a strategy to achieve their ends. Litigation was used to delay, compel, and concentrate legislative and administrative activity. Thus, just as food stamp supporters used litigation to frustrate action during the 94th Congress, advocates for the disabled used district court rulings to spur Congress to enact the EAHCA. In the AFDC, food stamps, and education of

58. Gerald N. Rosenberg, the hollow hope: Can Courts bring about Social Culaige? (1991).

59. Id at 336.

60. Id. at 338 .

61. Id at 341 .

62. Id. at 339 .

63. Id. at 341 .

64. Peter H. Schuck, Public Law Litigation and Social Reform, 102 YALE LJ. 1763, 1771-72 (1993) (book review). Other recent works bearing on the role of courts and social change include Gene $B$. Sperling, Does the Supreme Coutt Matter, in The AMERICAN Prospect ReAder in AMERICAN POLmCS 378 (Waiter Dean Burnham ed., 1995); Stephen L. Carter, Do Courts Master?, 90 MiCH. L. Rev. 1216 (1992); Neal Devins, Judicial Marters, 80 CAL. L. REV. 1027 (1992) (review essay). 
the handicapped programs, reformers used litigation as leverage to create opportunities for activity in other political spheres. For instance, the Supreme Court's early AFDC decisions allowed the Department of Health, Education, and Welfare to adopt a harder line with the states. The financial pressures placed on state and local governments by the PARC $C^{65}$ and Mills ${ }^{66}$ decisions moved their officials to turn to Washington, D.C., for federal assistance; advocates for the disabled then insisted that as a condition of receiving federal money schools demonstrate their compliance with court rulings.

If Melnick convincingly shows the impact of the federal courts-in each of the three programs examined the judiciary expanded their scope and shifted power from the states to the federal government-he also demonstrates conclusively the ways in which statutory decisions can affect policy and process. A focus solely on constitutional law to the neglect of statutory cases skews understanding of the role of the judiciary. Melnick supplies the missing pieces.

\section{B. Lessons for Theorists of Statutory Interpretation}

Proponents of various conceptions of statutory interpretation will learn much from Between the Lines, as the case studies demonstrate both the utility and limits of several approaches.

\section{Public Interest Theory}

The complexities of legislation, illuminated in the book, raise questions about the "public interest" approach advocated by Hart and Sacks, ${ }^{67}$ among others. ${ }^{68}$ This approach, much like the Madisonian vision, assumes that the legislative process and legislative decisions are deliberative, informed, and efficient. According to this view, every statute and every doctrine of unwritten law has some kind of purpose or objective. ${ }^{69}$ Thus, a judge who seeks to understand unclear wording first identifies the purpose and policy it embraces, and then deduces the result most consonant with those goals.

To be sure, this perspective provides an important antidote to the traditional canons of statutory construction. Its thrust is to try to understand the meaning of statutes in their own context, with appropriate resort to the process that produced the law, encompassing relevant legislative history. The flexible

65. Pennsylvania Ass'n for Retarded Children v. Pennsylvania, 343 F. Supp. 279 (E.D. Pa. 1972).

66. Mills v. Board of Educ., 348 F. Supp. 866 (D.D.C. 1972).

67. HeNRY M. HaRT, JR. \& Albert M. SACKS, The Legal Process: Basic Problems in the Making AND Application of Law (William N. Eskridge, Jr. \& Philip P. Frickey eds., 1994).

68. See, e.g., Alexander M. Bickel \& Harry H. Wellington, Legislative Purpose and the Judicial Process: The Lincoln Mills Case, 71 HARV. L. REv. 1, 15-17 (1957); Felix Frankfurter, Some Reflections on the Reading of Statutes, 47 COLUM. L. REv. 527, 534-38 (1947).

69. HART \& SACKS, supra note 67 , at $143,161-65$. 
nature of the inquiry suggested by this approach means that judges could extend the rationale of a statute to cover new circumstances, even those not envisioned when the legislature enacted the law. Whatever its virtues, however, this "public interest" perspective cannot by itself capture the complexities of the legislative process. Not infrequently, legislation is a collection of ambiguous and contradictory statements; this is a special problem with regard to large omnibus bills and measures that are rushed through Congress at the end of an exhausting session. For such statutes, it is something of a fiction to presume that Congress had a clear statutory purpose or that a court can infer with any certainty the legislative vision of the public interest.

The case studies of Between the Lines reflect this by depicting the "[m]any [f]aces of Congress," expansion of the food stamp program because it would increase money poor families could spend on items besides food. Others voted for it because they believed it would upgrade the nutrition of poor families. With regard to AFDC, most legislators, Melnick believes, probably voted for the AFDC amendments because they were part of a large social security measure." Some may have voted for it because it provided new services to recipients; still others saw it as a warning to the states to crack down on welfare. With respect to the EAHCA, some supporters thought that it would add federal funds without imposing extensive federal control over local school systems; others thought it would offer disabled students a variety of new services; still others were of the view that Congress should be responsive to judicial decisions establishing rights of the disabled; and a few believed that Congress should move because the Supreme Court might undo lower court decisions. ${ }^{2}$ The point, in short, is that Congress consists of a wide variety of legislators, with differing views of the public good, all of which are not simply captured by the "public interest" conception.

\section{Public Choice Theory}

The findings of Between the Lines also pose challenges to the "public choice" school, which uses principles of market economics to explain decision making. ${ }^{73}$ Like many schools, its scholars are not all of one mind, and cannot

70. MELNICK, supra note 14, at 256. On this point, see Kenneth A. Shepsle, Congress Is a "They;" Not an "It": Legislative Intent as Oxymoron, 12 INT'L REV. L. \& ECON. 239 (1992) (arguing notion of single legislative intent is misguided given multiplicity of legislators).

71. MELNICK, supra note 14, at 259.

72. Id.

73. For a discussion of the subject, see Daniel A. FARBer \& PHILI P. Frickey. LAW ANd PUbLIC

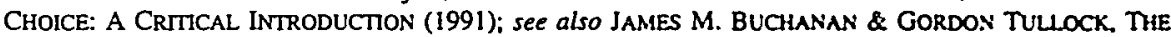
CALCULuS of CONSENT (1962); William C. Mitchell \& Michael C. Munger. Economic Mrodels of Interest Groups: An Introductory Survey, 35 AM. J. POL. SCI. 512 (1991): Susan Rose-Ackerman. Progressive Low and Economics-And the New Administrative Law, 98 YALE L.J. 341 (1988). 
be simply characterized. ${ }^{74}$ Generally though, its proponents depict the legislative process as driven by rational, egoistic, utility-maximizing legislators whose primary motivation is to be returned to office. On this view, legislators will pass laws that tend to transfer wealth and reduce efficiency, at the expense of society, to cohesive special interest groups that lobby the legislature. Laws benefiting the public will be scarce because of the "collective action" problem. That is, "rational, self-interested individuals will not act to achieve their common or group interests"75 because the benefits being sought are collective to the group as a whole; hence the rational individual has an incentive to be a free rider. It is thus by no means automatic that interest groups will arise to press legislators to enact "public interest" legislation.

Sharply different from the "public interest" conception, this vision of the legislature is grim. Legislators, eager to be reelected, avoid choices on critical issues that could antagonize energized groups. They do not work to develop coherent policy, but instead seek to accommodate the preferences of interest groups through ad hoc bargaining. Evading their responsibility, legislators adopt vague statutes vesting policymaking duties in administrators who must stumble through a mine field of unresolved problems.

Public choice theory encourages us to think about how self-interest affects decision making, to evaluate the impact of incentives on behavior, and to explore why collective action is often difficult to undertake. ${ }^{76}$ But the theory hardly explains the universe of the legislative process. ${ }^{77}$ The motivations of legislators are complex and cannot be reduced to simple formulae. The view that legislators simply respond to interest groups, that their behavior, votes, and agenda are dictated by those interest groups, and that they simply transfer wealth to those groups in return for campaign support is askew. As studies have shown, Congress can respond without much interest group support, ${ }^{78}$ often despite powerful and intense interest group opposition. ${ }^{79}$ To be sure,

74. See, e.g., Frank H. Easterbrook, The Supreme Court, 1983 Term-Foreword: The Court and the Economic System, 98 HARV. L. REV. 4 (1984); Richard A. Epstein, Toward a Revitalization of the Contract Clause, 51 U. CHI. L. REV. 703 (1984); Jonathan R. Macey, Promoting Public-Regarding Legislation Through Statutory Interpretation: An Interest Group Model, 86 CoLUM. L. REV. 223 (1986); Geoffrcy P. Miller, Public Choice at the Dawn of the Special Interest State: The Story of Butter and Margarine, 77 CAL. L. REV. 83 (1989).

75. MANCUR Olson, JR., The Logic of Collective ACtion 2 (1965) (emphasis omitted).

76. James Q. Wilson, Interests and Deliberation in the American Republic, or Why James Madison Would Never Have Received the James Madison Award, 13 PS: POL. SCI. \& POL. 558-62 (1990).

77. An earlier theory of interest group politics, the pluralist conception, suggests more favorably that legislative outcomes reflect the competition and equilibrium of competing interest groups, which foster both stability and orderly change. See, e.g., ROBERT A. DAHL, WHO GOVERNS? DEMOCRACY AND POWER IN an American City (1961); David TRUMAN, THE Governmental Process (1951).

78. MARTHA DERTHICK \& PAUl J. QUIRK, THE POLITICS OF DEREgulation 13 (1985) (noting that deregulation occurred without support of organized interests); KATZMANN, supra note 13, at 189 (noting that section 504 of Rehabilitation Act of 1973 was enacted without interest group impetus).

79. On the role of interest groups generally, see, for example, PHILIP A. MUNDO, INTEREST GROUPS: Cases and Characteristics (1992); Kay LeHMaN SCHLOZMAN \& JoHN T. TIERNEY, ORGanized INTERESTS AND AMERICAN DEMOCRACY (1986). 
legislators are responsive to the need to be reelected. ${ }^{80}$ But they are also affected by a desire to affect policy in ways that they think are in the public interest. $^{81}$ The better view, as James Q. Wilson has written, may be that legislation can have a wide variety of political causes, and that if we are to understand outcomes, then we need to specify the circumstances under which one or another cause will be operative. ${ }^{82}$

All this is confirmed in Melnick's account ${ }^{83}$ Traditional interest groups hardly played a role in the passage of the legislation that is the focus of Melnick's study. Business groups had almost no influence. Farm groups provided little support to the food stamp program. The Chamber of Commerce, which sought to cut food stamps in the mid-1970's, did not prevail. Those groups that were successful-for example, the National Association for Retarded Citizens, the Council for Exceptional Children, the intergovernmental lobby, and the "hunger lobby"-had neither wholly economic nor very welldefined interests. Melnick describes how many of the legislators in these cases were motivated by deeply held convictions about the public interest, rather than a desire to do what best suited their electoral interests or to keep their power in Congress. ${ }^{84}$ Russell Long and Thomas Foley played leading roles in the AFDC and food stamp cases, respectively, because of their conceptions of what constituted good public policy. ${ }^{85}$ The debate in all three case studies illustrated that politics is messy, with outcomes seldom free of ambiguity. Such is the consequence of a pluralistic system in which values compete.

\section{Positive Political Theory}

Positive political theorists will also benefit from the stories Melnick provides. These analysts have attempted to explain why Congress often finds it difficult to overturn court decisions even when the rulings at issue contravene an agreement of the winning and still-present legislative coalition. ${ }^{86}$ Through his examination of the food stamp program, Melnick offers a cogent explanation. If one part of the original coalition favors the court's decision over the legislative agreement, and if the remaining members of the coalition cannot gather sufficient support to replace the lost votes, then the judicial ruling will stand. ${ }^{87}$ Thus, before the Trump ${ }^{88}$ decision, food

80. See, e.g., DAVID R. MAYHEW, Congress: The EllectorAl CONNECTION 13 (1974). 1990).

81. See, e.g., Rober B. Reich, Introduction to THE POWER OF PUBLC IDEAS 3 (Robert B. Reich ed.,

82. James Q. Wilson, The Politics of Regulation, in THE POLTICS OF REGULATION 357, 364-72 (James Q. Wilson ed., 1980).

83. See MELNICK, supra note 14, at 260.

84. Id.

85. Id.

86. See, e.g., Matthew D. McCubbins et al., Structure and Process, Politics and Poltcy: Adminisirartve Arrangements and the Political Control of Agencies, 75 VA. L. REv. 431.445 (1989).

87. MELNICK, supra note 14 , at 261 . 
stamp advocates felt that they had to reach an accommodation with President Ford; after the ruling, they were more willing to wait for a new President and Congress. ${ }^{89}$

Attempting to explain the reasons for legislative success in overturning court rulings in the case studies, Melnick offers two theories: First, strategically placed committee leaders had the power to protect court decisions they favor and to move along legislation modifying decisions they sought to change; ${ }^{90}$ and second, most overrides were lodged in larger financing bills that provided a measure of convenient protection from scrutiny. ${ }^{91}$

Nevertheless, in spite of the obstacles to legislative action that rational choice theorists have noted, ${ }^{92}$ Melnick's case studies show that Congress does in fact modify or reverse judicial rulings. The 1977 food stamp amendments changed a number of court rulings on benefits and eligibility. ${ }^{93}$ Congress overturned the Supreme Court's decision on attorneys' fees through enactment of the Handicapped Children Protection Act. ${ }^{94}$ It also reversed a Supreme Court ruling limiting parents' rights to collect damages from the states. ${ }^{95}$ Between 1981 and 1984, Congress upset a number of AFDC decisions. ${ }^{96}$ The findings of these case studies are consistent with the work of William $\mathrm{N}$. Eskridge, Jr., who has provided data indicating that since 1975 Congress reversed or modified at least 300 lower court and 100 Supreme Court rulings. ${ }^{97}$

Positive political theorists interested in how legislators structure the rules of the "game" that will later be played as agencies and courts attempt to make sense of a newly passed statute will also find Between the Lines an important empirical source. How legislators write the laws can be powerful signals of legislative meaning to courts and agencies. ${ }^{99}$ A detailed statute may

88. Trump v. Butz, No. 76-933 (D.D.C. June 18, 1976).

89. MELNICK, supra note 14, at 217.

90. Id. at 263.

91. Id.

92. See id. at 261 (describing "multiple veto points in the legislative process").

93. Id. at 221.

94. Id. at 175-76.

95. Id. at 176.

96. Id. at 104 .

97. William N. Eskridge, Jr., Overriding Supreme Court Statutory Interpretation Decisions, 101 YALB L.J. 331 (1991).

98. See, e.g., William N. Eskridge, Jr., Reneging on History? Playing the Court/Congress/President Civil Rights Game, 79 CAL. L. REV. 613 (1991); see also KEITH KREHBIEL, INFORMATION AND Legislative Organization (1991); John A. Ferejohn \& Charles R. Shipan, Congressional Influence on Administrative Agencies: A Case Study of Telecommunications Policy, in CONGRESS RECONSIDERED 393 (Lawrence C. Dodd \& Bruce I. Oppenheimer eds., 4th ed. 1989); John Ferejohn \& Charles Shipan, Congressional Infiuence on Bureaucracy, 6 J.L. ECON. \& ORGANIZATION 1 (1990); John Ferejohn \& Barry Weingast, Limitation of Statutes: Strategic Statutory Interpretation, 80 GEO. L.J. 565 (1992); Matthew D. McCubbins et al., Administrative Procedures as Instruments of Political Control, 3 J.L. ECON. \& ORGANIZATION 243 (1987); Edward P. Schwartz et al., A Positive Theory of Legislative Intent, 57 LAW \& CONIEMP. PROBS. 51 (1994).

99. See Robert A. Katzmann, The American Legislative Process as a Signal, 9 J. PUB. POL'Y 287, 292 
be the clearest way to communicate to the other branches; but at times in the effort to reach an agreement members of Congress will pass vague statutes, deliberately leaving such controversies to be resolved by administrators and judges. Congress has a variety of mechanisms to affect administrators and judges. It can determine the powers of administrative agencies, the standards for exhaustion of administrative remedies, the scope and availability of judicial review, the limits of standing to sue, where suits must be filed, what remedies to allow, and the availability of attomeys' fees.

Melnick demonstrates that although legislation is often crafted without much thought to these issues, at times Congress actively pays attention to at least some of them. ${ }^{100}$ Thus, negotiations leading to passage of the EAHCA involved considerable discussion about judicial review of school decisions, with advocates of the disabled supporting a more stringent standard than state and local systems. ${ }^{101}$ To the extent that strategic calculations of this sort are made about how to structure judicial review, members of Congress are likely to be influenced by factors such as their perceptions of administrative and judicial competence, their ability to exercise post hoc control (greater with respect to administrators than judges), and the degree to which judicial review is sought by an important element of the coalition needed to secure passage of the final legislation. ${ }^{102}$ Melnick also suggests that members of Congress are likely to encourage judicial review when "they favor program expansion and bear little responsibility for footing the bill."103 That explanation has a temporal quality, and depends upon the existence of a judiciary that supports such expansion-not necessarily so, as judges appointed in the 1980's would probably attest.

\section{Textualist Theory}

Textualists ${ }^{104}$ reading Between the Lines will find some support for their claim that legislative history is unreliable, that citing it, in the words of Judge Harold Leventhal, is like "looking over a crowd and picking out your friends." ${ }^{105}$ But those textualists who believe that committee reports are invariably successful devices by which committee members and staff promote their policy preferences may be forced to reassess their assumptions upon review of Melnick's case studies. In neither the food stamp program nor

(1990).

100. MELNICK, supra note 14 , at $269-70$.

101. Id. at 270 .

102. Id. at $272-73$.

103. Id. at 272 .

104. See, e.g., Frank H. Easterbrook, The Role of Original Intent in Statusory Construction. 11 Hakv. J.L. \& PUB. POL'y 59 (1988); Kenneth W. Starr, Observations About the Use of Legislatwe History. 1987 DUKE L.J. 371; sources cited supra note 4.

105. See MELNICK, supra note 14, at 251 (quoting Judge Leventhal). 
AFDC was the legislative history relied upon by the court manufactured or manipulated by the members or staff of committees with legislative jurisdiction over the programs. ${ }^{106}$ In fact, at times committee chairs felt frustrated that the courts had either ignored or failed to interpret correctly key aspects of the legislative history. ${ }^{107}$ Assessing the role of legislative history generally in the case studies, Melnick concludes that references to it were "little more than window dressing designed to provide additional support for positions arrived at by other means." ${ }^{108}$ Of greater significance in his view than the use of legislative history to the courts' interpretation of statutes were the assumptions judges made about separation of powers, federalism, and the nature of individual rights. ${ }^{109}$

\section{CONGRESS AND tHE Courts: Clarifying Legislative MeANing}

Legislative history might very well have played a more important role in judicial interpretation if Congress had developed more reliable signals to the courts as to its use. The more authoritative Congress is as to the appropriate use of such material, the more likely that legislative history will have the intended weight. Legislative history, in my view, is a necessary component of judicial inquiry, especially when a statute's meaning is not clear on its face and a court needs guidance. ${ }^{110}$ As Justice Breyer has written, the problem lies not in its use, but its abuse. ${ }^{111}$ Thus, it is imperative that Congress develop means to clarify the use of such materials if courts are to better interpret legislative meaning.

Discerning legislative meaning is often a difficult task. Consider the following typical pattern. Congress enacts a law and the statute becomes the object of litigation. The court must then interpret the meaning of the words of the statute. Yet the language is often unclear. As the judiciary looks for guidance, it delves into the legislative history-the foundation on which most judges seek to interpret statutory meaning. In so doing, the court must

106. Id. at 252.

107. Id.

108. Id. at 253.

109. Id. at 238-51.

110. My views on this subject are further developed in my forthcoming book, CouRTS AND CONGRESS: REFLECTIONS FROM THE FIELD (forthcoming Nov. 1995). On this point, see, for example, DYNAMIC STATUTORY INTERPRETATION, supra note 8, at 225-38; Breyer, supra note 5; George A. Costello, Average Voting Members and Other "Benign Fictions": The Relative Reliability of Committee Reports, Floor Debates, and Other Sources of Legislative History, 1990 DUKE L.J. 39; Michael Livingston, Congress, the Courts, and the Code: Legislative History and the Interpretation of Tax Statutes, 69 TBX. L. REV. 819 (1991); Abner J. Mikva, A Reply to Judge Starr's Observations, 1987 DUKE L.J. 380; Stephen F. Ross, Reaganist Realism Comes to Detroit, 1989 U. ILL. L. Rev. 399; Patricia M. Wald, The Sizzling Sleeper: The Use of Legislative History in Construing Statutes in the 1988-89 Term of the United States Supreme Court, 39 AM. U. L. REV. 277 (1990); Nicholas S. Zeppos, Justice Scalia's Textualism: The "New" New Legal Process, 12 Cardozo L. REV. 1597 (1991).

111. Breyer, supra note 5 , at 874 . 
determine in the first instance what constitutes legislative history and how to weigh its various parts: including committee reports, conference committee reports, floor debates, and votes. The court may have to penetrate layer upon layer of rules and procedures. At times, the legislative history is virtually nonexistent. In other situations, it is ambiguous. In particular cases, Congress deliberately does not deal with difficult issues. In other circumstances, the legislature might have chosen to avoid gaps and ambiguities had it been aware of the problem. When Congress has not addressed an issue the court may be asked to fill in gaps not only in the statutory language, but also in the statute itself. For example, Congress may not have addressed questions of preemption, attorneys' fees, civil statutes of limitations, constitutional severability provisions, private rights of action, exhaustion of administrative remedies, and the nature of the administrative proceedings.

Congressional organization and process-early targets for the House leadership of the 104th Congress-also contributed to the difficulty of discerning legislative intent in Melnick's case studies. In some ways, fragmentation increased, staffs grew substantially, subcommittees proliferated, and the opportunities for legislative entrepreneurship, in ways unobserved by the whole chamber, expanded as well. ${ }^{112}$

What this all means is that when Congress does not give explicit direction about its legislative meaning, it not only creates added burdens for the courts: It also increases the risk that the judiciary, in a good faith effort to make sense of the problems before it, will interpret statutes in ways that the legislature did not intend. It is, of course, too much to expect that institutions will act with perfect knowledge. Given the political and policy complexities surrounding many issues, it is unrealistic to believe that those institutions can definitively address all the problems they face. Indeed, sometimes legislation is purposely ambiguous, and legislative history will not provide the key to unlock congressional meaning. But often Congress could be clearer as to its meaning if only attention were paid, and legislative history could be a valuable tool if only its indicators were more reliable.

To be sure, what the role of the judiciary in reviewing legislation should be is in no small measure dependent upon subjective perspectives about the proper allocation of responsibilities among courts, Congress, and various parts of the administrative branch-about what tasks we think each institutional process should assume. Such perspectives are based upon assumptions about how Congress functions, the factors affecting legislative outcomes, and the ability of the judiciary to make sense of congressional intent. Any of these conceptions should to one degree or another share this objective-based upon

112. As an empirical matter, it will be interesting to observe whether a tightening of congressional organization and reduction in staff, as promised by the new congressional leadership. will affect the capacity of Congress to develop legislative history that is more authoritative. 
an empirical examination of the way Congress works, to ascertain how courts can better interpret statutory meaning and to determine whether and how Congress can clarify legislative history. Theories about how courts should interpret legislative history can be advanced with greater confidence to the extent that they are informed by an appreciation of the complex reality of the legislative process.

If the foregoing analysis is correct, then at bottom ways should be found for courts to better understand the legislative process and legislative history and for Congress to more clearly signal its intent. Time could be spent pondering what can be done in the long term about the legislative fragmentation, the conflicts among committees, the difficulties in making tradeoffs, and the problems of deliberation in Congress-all of which contribute to the courts' difficulties in understanding the legislative process. ${ }^{113}$ But there are more immediate steps that could be taken. In the short term, Congress can clarify legislative meaning in three ways: through more precise drafting, more authoritative legislative histories, and refinement of the revision process. ${ }^{114}$

\section{A. Drafting}

Greater attention to legislative drafting would make it more likely that congressional intent will be understood and respected. If Congress is concerned that judicial doctrines have vested executive agencies with too much power to interpret statutes, then legislators can strive to write bills with greater

113. For an excellent analysis, see THOMAS E. MANN \& NORMAN J. ORNSTEIN, RENEWINO CONGRESS: A SECOND REPORT 84-86 (1993).

114. In discussing each of these approaches, I draw upon ongoing work of the Governance Institute, undertaken with the support of the Brookings Institution. Founded in 1986, the Governance Institute is a nonprofit organization concerned with exploring, explaining, and easing problems associated with both the separation and the division of powers in the American federal system. The Institute's focus is on institutional process, a nexus linking law, institutions, and policy. It has three program areas: problems of the judiciary; problems of the administrative state; and challenges to the legal profession. Working with decision makers in the federal judiciary and the Congress, the Institute's project on judicial-congressional relations has three principal parts: (1) examining the kinds of ground rules, protocols, and factors to be considered for different types of communications between the branches; (2) exploring how courts can better understand the legislative process and legislative history, how Congress can better signal its intent in statutes, and how the judiciary can make the legislature more aware of its decisions interpreting statutes; and (3) assessing the institutional processes and mechanisms that might improve relations between the branches.

Among the products of the Governance Institute project on judicial-legislative relations are: Hearings on Interbranch Relations, supra note 7, at 298-312, 276-78 (statements of Robert A. Katzmann and Robert W. Kastenmeier); Hearings on Statutory Interpretation, supra note 6, at 128 (statement of Robert A. Katzmann); JUDGES AND LEGISLATORS, supra note 4; Frank M. Coffin, Communication Among the Three Branches: Can the Bar Serve as Catalyst?, 75 JUdICATURE 125 (1991); Robert A. Katzmann, Bridging the Statutory Gulf Between Courts and Congress: A Challenge for Positive Political Theory, 80 GEO. L.J. 653 (1992) [hereinafter Katzmann, Bridging the Statutory Gulf]; Robert A. Katzmann, Building Bridges: Courts, Congress, and Guidelines for Communications, BROOKINGS REV., Spring 1991, at 42 [hereinafter Katzmann, Building Bridges]; Russell R. Wheeler \& Robert A. Katzmann, Project Seeks To Improve Communications Between Courts and Legislatures, 75 JUDICATURE 45 (1991). 
precision. ${ }^{115}$ They may attempt in legislation itself to define the degree of deference that should be granted to executive agencies in interpreting statutes. Although court cases are likely to arise over whether such efforts would usurp the executive and judicial functions, I am not without hope that carefully drafted provisions in legislation about questions of deference could prevail.

With respect to drafting, it would be useful to determine if some way could be found to subject such activity to centralized scrutiny applying accepted standards. The House of Representatives and the Senate have offices of legislative counsel, trained in the nuances of drafting. A checklist ${ }^{116}$ of common problems could be prepared for the benefit of those in Congress who do not use the professional drafting services. Such a checklist would focus legislators' attention on such matters as constitutional severability, civil statutes of limitations, attorneys' fees, private rights of action, preemption, and exhaustion of administrative remedies. These issues, when they are not explicitly addressed in the legislation itself, are often left to the courts for resolution. Establishing a means to focus legislative attention on these issues could reduce judicial burdens and give clearer direction as to legislative intent. To improve drafting, periodic seminars involving legislative counsel and judges would be useful. The Governance Institute, a nonprofit organization with which $\mathrm{I}$ am involved, is engaging in efforts to promote such activity. ${ }^{117}$

\section{B. Legislative History}

Authoritative legislative histories should be completed prior to final passage. Legislative signals of intent could be made clearer, particularly if the most important and agreed-upon background and purposes of the legislation can be more sharply identified.

Consider the significance to be attached to committee reports. Assuming they are to be given weight as courts seek to understand statutory meaning, attention should be paid to devices that make it more likely that committee reports receive positive congressional assent. There are ways to distinguish between those parts of committee reports that receive such affirmative approval and those that do not. At the very least, as Professor Stephen Ross has noted,

115. At least part of the difficulty of achieving clarity comes from the porous nature of the congressional process in which bills and amendments can be introduced without review by the professional drafters. In Britain, where party loyalty and executive-dominated govemment chancienze the parliamentary system, highly trained civil servants write the laws with greater precision. See Patrick S. Auyah. JutictalLegislative Relations in England, in JUDGES AND LEGISLATORS, supra note 4, at 129, 155-61.

116. On checklists, see, for example. Robert A. Katzmann. The Continuing Challenge. in JuDGES AND LEGISLATORS, supra note 4, at 180, 183-84; see also FEDERAL. BAR CounCIL COMIM. ON THE SECOND CIRCUIT COURTS, A REPORT ON JUDICIAL IMPACT LEGISLATION (Dec. 15, 1989); FEDERAL COURTS STUDY COMM., JUdiCIAL CONFERENCE OF THE U.S., REPORT OF THE FEDERAL COURTS STUdY COMIMITtEe 91 (1990).

117. For further discussion of the Govemance Institute's activities, see supra note 114. 
it would be desirable if committee members signed committee reports. ${ }^{118}$ At present, only the chair and those presenting additional views sign the reports, leading to charges that they may lack majority support. Having committee members sign the report would blunt at least that part of the critique of legislative history which holds that not even legislators assigned to committees are cognizant of committee reports.

As legislation nears passage, the floor managers of legislation should strive to reach some agreement as to what constitutes authoritative legislative history. Thus, they would reach some shared understanding as to which floor statements and colloquies should be given weight and indicate that such material by express arrangement is meant to be part of the authoritative legislative history. ${ }^{119}$ Such a procedure might make it easier for judges to interpret the Congressional Record-a document that can be easily manipulated, and that is in many instances a source of hopeless confusion.

Congressional concern with making legislative history more authoritative will also aid courts as they weigh the amicus briefs of legislators seeking to influence the judiciary's view about legislative intent. At times, legislators who have failed to secure their objectives in the congressional arena try to secure their ends through the judiciary. To the extent that legislative materials become more authoritative, courts will be better able to evaluate amicus briefs and ascertain congressional meaning.

\section{Statutory Revision}

As Congress revises statutes, it might draw upon the experience of courts charged with interpreting its laws. For example, when a committee of Congress is considering revising a complex piece of legislation, it might be useful for judges experienced in interpreting statutes to testify as to the technical difficulties in discerning congressional meaning. Although the courts and Congress affect each other in many ways, uncertainty about the propriety of various kinds of communications inhibits useful input. ${ }^{120}$ Accordingly, the

118. Stephen Ross, Where Have You Gone, Karl Llewellyn? Should Congress Turn Its Lonely Eyes to You?, 45 VAND. L. REV. 561, 575 (1992).

119. I recognize, of course, that even such agreements may be subject to differing interpretations. A case in point is the discussion about the meaning of what constitutes the terms of the "exclusive legislative history" of the provisions of the 1991 Civil Rights Act. See, e.g., 137 CONG. REC. H9526-32 (daily ed. Nov. 7, 1991) (statement of Rep. Edwards); id. at H9533-35 (statement of Rep. Ford); id. at H9542-49 (statement of Rep. Hyde); 137 CONG. REC. S15,952-53 (daily ed. Nov. 5, 1991) (statement of Sen. Dole); 147 CONG. REC. S15,472-78 (daily ed. Oct. 30, 1991) (statement of Sen. Dole); 137 CoNG. ReC. S15,315-24 (daily ed. Oct. 29, 1991) (statement of Sen. Hatch); id. at S15,325 (statement of Sen. Danforth); 137 CONG. REC. S15,233-35 (daily ed. Oct. 25, 1991) (statement of Sen. Kennedy).

120. See Frank M. Coffin, The Federalist Number 86: On Relations Between the Judiciary and Congress, in JUDGES AND LEGISLATORS, supra note 4, at 21; Katzmann, Building Bridges, supra note 114, at 42. As chair of the Subcommittee on Courts, then Congressman Robert Kastenmeier would from time to time draw upon such expertise. But generally, Congress does not avail itself of this opportunity, largely because of the uncertainty of judges and legislators about such communication. See, e.g., Fair Use and 
development and refinement of communications protocols between judges and legislators with regard to statutory revision would be helpful. ${ }^{12}$

Moreover, Congress would benefit from the states' experiences with law revision commissions that provide for the orderly evaluation of statutes by bringing together representatives of all three branches. ${ }^{122}$ It would also be worthwhile to develop mechanisms to facilitate the congressional resolution of conflicts among the circuits with respect to legislative meaning, as Justice Stevens $^{123}$ and Judge Wilfred Feinberg ${ }^{124}$ have recommended. Then Judge Ruth Bader Ginsburg and her coauthor Peter Huber advanced the idea that a "second look at laws" committee be formed, and that the Office of Law Revision Counsel assist in "statutory reexamination and repair."125 Judge Frank M. Coffin suggested that an entity within the judiciary gather and sift judicial opinions with suggestions for the legislative branch and send them to the Hill, ${ }^{126}$ a view endorsed more recently by Judge James L. Oakes of the U.S. Court of Appeals for the Second Circuit. ${ }^{127}$

A practical component of this effort to make the process of statutory revision more rational is a pilot project, which the Governance Institute began at the invitation of the judges of the U.S. Court of Appeals for the D.C. Circuit. ${ }^{128}$ In that work, we helped design a system of collecting, sorting, and circulating statutory opinions of the D.C. Circuit to relevant congressional committees for legislative consideration.

In the effort to help close the gap between those who produce legislative history and those who digest it, Judge Coffin and I conducted a study to determine how judicial decisions identifying problems in legislation are examined by Congress. ${ }^{129}$ We found that in most cases, except for major

Unpublished Works: Joint Hearing Before the Subcomm. on Patents, Copynghts, and Trademarks of the Senate Comm on the Judiciary and the Subcomm on Courts, Intellectual Property, and the Administration of Justice of the House Comm. on the Judiciary, 101 st Cong., 2d Sess. 81-143 (1990) (testimony of Judge James L. Oakes, Judge Roger J. Miner, and Judge Pierte N. Leval).

121. Katzmann, Building Bridges, supra note 114 , al $42-43$.

122. Guido CALABResi, A COMMON LAW fOR the AGE OF STATUtes $63-64$ (1982); hans A. Lunde, Observations of a State Judge, in JUDGES AND LEGISLATORS, supra note 4, at 121. 127; Shirley S. Abrahamson \& Robert L. Hughes, Shall We Dance? Steps for Legislators and Judges in Statutory Interpretation, 75 MiNN. L. REv. 1045, 1070-72 (1991).

123. See John Paul Stevens, Some Thoughts on Judicial Restraint, 66 JUDICATURE 177. 183 (1982).

124. See Wilfred Feinberg, Foreword: A National Court of Appeals?, 42 BROOK. L. REV. 611,627 (1976).

125. Ginsburg \& Huber, supra note 5, at 1432.

126. Interview with Chief Judge Frank M. Coffin, Third Branch, June 1982, at 1, 6.

127. James L. Oakes, Grace Notes on "Grace Under Pressure". SO OHIO ST. L.J. 701. 714-15 (1989).

128. The Govemance Institute's project was encouraged by the special interest of then Chicf Judge Patricia M. Wald, Judge James L. Buckley, then Judge Ruth Bader Ginsburg, and former Judge Abner J. Mikva.

129. We selected 15 cases, suggested by the judges of the D.C. Circuit. Some problems involved questions of grammar, such as misplaced commas and ambiguous adjectives. Other laws had iechnical gaps. such as failing to state which courts had jurisdiction over cases that could be brought under the stalutes. In still other cases, the courts explicitly invited congressional action to clear up ambiguities. See Proceedings of the Forty-Ninth Judicial Conference of the D.C. Circuit. Panel II-Congress and the Judiciary: An Inquiry into Problems of Statutory Construction and Revision. 24 F.R.D. 312. 318-21 (1988): 
ones or those in which a losing party seeks legislative relief, congressional staffs are generally unaware of circuit court rulings. Having determined that staffs wanted to be informed of relevant opinions, the Governance Institute, in close collaboration with then Chief Judge Mikva, proceeded to work out an arrangement with the House of Representatives and the Senate whereby offices in each chamber would receive the opinions and transmit them to the relevant committees. ${ }^{130}$ Other circuits-the First, Third, Seventh, and Tenth-have joined this initiative, with others expected to become a part as well. In its report to the Judicial Conference, the Committee on Long Range Planning recommended that "[a]11 courts of appeal should be encouraged to participate in the pilot project."131 Recently, the Joint Committee on the Organization of Congress endorsed our enterprise. ${ }^{132}$

Both branches benefit from this project. Congress will have an enhanced appreciation for the judiciary's work, and the courts' workload may be somewhat reduced if Congress improves drafting or resolves problems in statutes identified by the judiciary. In addition, as the Governance Institute monitors congressional reaction to court decisions, we will have a better sense of congressional views about judicial interpretation of statutes. As the Governance Institute analyzes the data from both the judiciary and Congress, and holds seminars involving all those who work with statutes, the objective is to upgrade the drafting, interpretation, and revision of statutes-a purpose shared by the Legislative Counsels of both the House and Senate. ${ }^{133}$

Katzmann, Bridging the Statutory Gulf, supra note 114, at 656-58.

130. Governance Institute Distinguished Fellow Robert W. Kastenmeier and I did so after many discussions on the Hill, especially with the Legislative Counsel of the House, the Legislative Counscl of the Senate, and the Legal Counsel of the Senate. The bipartisan leadership of each branch-then Speaker Thomas Foley, then House Majority Leader Richard Gephardt, then House Minority Leader Robert Michel, then Senate Majority Leader George Mitchell, then Senate Pro Tempore Robert Byrd, and then Senate Minority Leader Robert Dole-launched the experiment in 1992.

In their memorandum of May 21, 1992, Foley, Gephardt, and Michel indicate that they "believe that the program would be most useful if it were applied to all circuits." Hearings on Interbranch Relations, supra note 7, at 309 (reprinting Letter of Foley, Gephardt, and Michel to Legislative Counsel David Meade). Senators Mitchell, Byrd, and Dole state that " $[t]$ his project offers great promise as a thoughtful and productive step in improving communications between the judiciary and the Congress to the benefit of both branches." Id. at 310 (reprinting Letter of Mitchell, Byrd, and Dole to Legislative Counsel Francis Burk). They note that the "hope is that the identification and transmittal of such opinions to the appropriate congressional committees will furnish information helpful to Congress's efforts to improve its communication of legislative intent in statutory drafting." Id. For his part, Chief Justice William $H$. Rehnquist, in the 1992 Year-End Report of the Federal Judiciary, pointed to the Governance Institute project as an effort to improve relations between the branches by making "it easier for judges to alert legislators to statutory drafting problems identified in the course of adjudication." William H. Rehnquist, Chief Justice Issues 1992 Year-End Report, THIRD BRANCH, Jan. 1993, at 1, 4.

131. Committee on Long Range Planning, Judicial Conference of the U.S., Proposed Lono RANGE PLAN FOR THE FEDERAL COURTS 119 (2d prtg. 1995) (recommendation 99e).

132. JoINT COMM. ON THE ORGANIZATION OF THE CONGRESS, FINAL REPORT, H. REP. No. 413, vol. II, S. REP. No. 215, vol. II, 103d Cong., 1st Sess. 25 (1993).

133. Letter from Francis L. Burk, Jr., Legislative Counsel, U.S. Senate, to Professor Robert Katzmann (Nov. 29, 1994) (on file with author); Letter from David E. Meade, Legislative Counsel, U.S. House of Representatives, to Robert W. Kastenmeier (Dec. 8, 1994) (on file with author). 


\section{CONCLUSION}

"To students of statutory interpretation," writes Professor Melnick, "no problem is more vexing than affixing a single meaning or intent to legislation that is the product of many hands." 134 But Congress is not without means to help facilitate understanding of its legislative product.

In Between the Lines, Shep Melnick challenges us to better understand the effects of judicial interpretation of statutes on policy and process. He does so with an impressive analysis that places his subject within the context of the division of power and responsibility among all three branches of government, while at the same time showing mastery of three dimensions of welfare policy. In so doing, Melnick stimulates us to appreciate not only how policy and process intersect, but how institutions can be made to work better. For all those insights, students of law, politics, and policy are much in his debt.

134. MELNICK, supra note 14, at 256. 
